\section{The Dickcissel}

\section{By ARTHUR WARD, Swift Current}

After becoming acquainted with members of the Thrush family one wonders why the bird we know as the Robin does not have the name "Redbreasted Thrush." Its actions, nest construction, and color of eggs are almost identical with those of the Eriglish Song Thrush, except that the latters stays more within the woodlands rather than the most unusual places around the dwellings of the cities, occupied by the American Robin.

The name "Dickcissel" too, seems to suggest something apart from the sparrow class to which it truly belongs. Though not a rare bird, it is uncommon in our district. Standing at the door one morning I observed the male and female feeding on the ground. Later on, not far along the creek side, whilst tramping through the long grass towards some rose bushes, where I had a Yellow Warbler's nest under observation, I suddenly flushed a bird. Although my feet were within six inches nothing at first was revealed, but on pushing aside the grass I saw the Dickcissel's nest, made of coarse grass and containing four pale blue eggs with brown blotches at the thick end. I photographed the nest in color.

Looking. along the creek towards the nest one morning I noticed two surveyors with tripod fixed so it seemed to be over the nest. I hurried over but found that they were a few yards from it. I showed it to them-they had never heard of such a bird.

I also recounted to them the details of the Yellow Warbler's nest in the rose bushes, referred to above. It contained two eggs-one the Warblers, the other a Cowbird's. The Warbler egg was smeared as though one had been broken. I took out the Cowbird egg, cleaned the Warbler egg and put it back in the nest. Returning two days later I found the nest to be empty. When I took the two surveyors to show them the empty nest, greatly to our surprise, we found that the Warbler had laid four more eggs. Afterwards these were successfully hatched out. I have seen this done before.

I wonder what observations have been made of the Dickcissal by other members of our Natural History Society.

\section{"As Swift as an Eagle in its Flight" \\ By M. A. WELSH, Prince Albert}

On June 5th, 1953 I was flying between Prince Albert and Stoney Rapids, a settlement very near the "top" of the province and very near to the centre in an east-west direction. Once we entered the remote area north of Lac La Ronge we noted a great many eagles, both Bald and Gclden. These eagles were mostly seen on the wing, hunting. Near Stoney Rapids (about 20 miles south) I noted one Bald Eagle circling about 500 feet from the plane and sightly above us. On checking the altimeter of the plane, I found that we were flying at about 5,000 feet. This eagle when flying in the same direction as we were, was equaling the plane's speed - about 125 miles an hour.

\section{Indigo Bunting}

\section{By S. O. JORDHEIM,}

White Bear, Sask.

I wish to report that I saw an Indigo Bunting on the morning of June 22. I managed to get within fifteen feet of it, and at that distance it reminded me of a Goldfinch, except that its body was blue instead of yellow.

On looking it up in the bird book I saw it could only be an Indigo Bunting, and as it says there, that it is a rare bird for Saskatchewan, I thought I would report it. I have never seen the bird since that morning. 